\title{
THE INFLUENCE OF CAPITAL STRUCTURE AND FIRM SIZE ON PROFITABILITY AND DIVIDEND POLICY (An Empirical Study at Property and Real Estate Sector Listed in Indonesia Stock Exchange during the periods of 2009-2012)
}

\author{
Evada El Ummah Khoiro, Suhadak, Siti Ragil Handayani \\ Faculty of Administrative Science, Brawijaya University Malang \\ Email: evedee33@gmail.com
}

\begin{abstract}
ABSTRAK
Penelitian ini dilakukan untuk meningkatkan pengetahuan tentang struktur modal, ukuran perusahaan, profitabilitas, dan kebijakan dividen. Penelitian ini dilakukan di sektor real estate yang terdaftar di Bursa Efek Indonesia (BEI) properti dan selama periode 2009-2012. Data dikumpulkan dari 36 laporan keuangan tahunan menggunakan purposive sampling. Hasil penelitian menunjukkan bahwa Struktur Modal memiliki pengaruh signifikan negatif terhadap Profitabilitas dan Ukuran Perusahaan memiliki pengaruh signifikan positif tetapi tidak pada Profitabilitas. Selain itu, Struktur Modal tinggi atau lebih rendah tidak mempengaruhi Kebijakan Dividen. Penelitian ini juga menunjukkan bahwa Firm Size signifikan positif mempengaruhi Kebijakan Dividen. Terakhir, Profitabilitas memiliki hubungan yang positif dan signifikan terhadap Kebijakan Dividen perusahaan properti dan real estate yang terdaftar di BEI. Penelitian ini bertujuan untuk memberikan saran yang baik untuk perusahaan manajemen dan investor di Indonesia, bahkan lebih untuk berkontribusi pada pengembangan penelitian keuangan, terutama di Struktur Modal, Ukuran Perusahaan, Profitabilitas, dan Kebijakan Dividen.
\end{abstract}

Kata kunci: Struktur Modal, Ukuran Perusahaan, Profitabilitas, Kebijakan Dividen

\begin{abstract}
The study conducted to enhance the knowledge about capital structure, firm size, profitability, and dividend policy. The study conducted at property and real estate sector listed in Indonesia Stock Exchange (IDX) during the periods of 2009-2012. Data were collected from 36 annual financial statements using purposive sampling. The result shows that Capital Structure has a negative significant influence on Profitability and Firm Size has positive but not significant influence on Profitability. Besides, higher or lower Capital Structure has no influence on Dividend Policy. The study also shows that Firm Size is significant positively influence Dividend Policy. Lastly, Profitability has a positive and significant relationship to Dividend Policy of property and real estate companies listed on IDX. The study is aim to provide a good suggestion for the management company and investor in Indonesia, even more to contribute to the finance research development, especially in Capital Structure, Firm Size, Profitability, and Dividend Policy.
\end{abstract}

Keywords: Capital Structure, Firm Size, Profitability, Dividend Policy 


\section{INTRODUCTION}

Economic growth is one of the measurements of a country's welfare. Indonesia's economic growth is supported by growth in the real sector, one of which is the construction sector, including the industrial property and real estate. Capital structure as the mix of different securities is crucial for business organizations (Abor, 2005), especially those in property and real estate sector. The required funds can come from many different sources and by different forms, either debt or equity capital to finance their assets (Azhagaiah and Gavoury, 2011).

The relationship between capital structure and profitability cannot be ignored because the improvement in the profitability is necessary for the long-term survivability of the firm. Several prior studies such as Shubita and Alsawalhah (2012); Azhagaiah and Gavoury (2011); Abor (2005); Gill et al. (2011); Tapanjeh (2006) investigate the relationship and found a contrary result.

Firm size as one of the factors influencing profitability also has been tested by various researchers. Some authors stated that firm size have positive significant relationship to profitability. Key features of a large firm are it diverse capabilities, larger economies of scale, and great competitive edge than their competitors, which put them in a position to earn a higher profit (Vijayakumar, 2011; John and Adebayo, 2013; Babalola, 2013). Meanwhile Tapanjeh (2006); Niresh and Velnampy (2014); and Pervan (2012) found that size may have no or weak impacts on profitability. Niresh and Velnampy (2014) reveals that the reason might because of shifted focus of managers from profit maximization to maximization of managerial utility, adamant organization structure, used technology, or a change in tactical logic.

Capital structure, firm size, and profitability have long been regarded as important factors influencing dividend policy. Investors may seek the return of income or the level of investment (return) in the form of dividends. Capital structure as the mixture of debt and equity is commits itself to fixed financial charges embodied in interest payments and the principal amount, and failure to meet these obligations may lead the firm into liquidation (Al-Malkawi, 2007). In other words, company prefers to pay their obligations rather than pay dividends. AlKuwari (2009) and Hasyemi et al. (2012) also stated that capital structure is statistically significant and negatively associated with dividend policy. On the other hand, the study conducted by Megawati (2011); Marlina and Danica (2009); Hardjopranoto (2006) found that capital structure has non-significant relation to dividend policy.

Firm size defined as the amount and variety of production or services capacity and ability a firm possesses is measured by natural logarithm of total assets and total sales. Al-Kuwari (2009); Al-Malkawi (2007); Hasyemi, (2012) stated that large firms are better able than small firms to distribute higher dividends to shareholders. Based on agency problem by Jensen and Meckling (1976) explained that dividends could play a role in helping to alleviate the agency problem. The larger the firm, the more difficult (costly) is the monitoring (i.e. the greatest the agency problem). Agency problem will leads the company face more delegacy costs because delegacy costs increasing complexities and in capability of shareholders.

Profitability has been regarded as the primary indicator of the level of dividends paid (Amidu and Abor, 2006; Al-Malkawi, 2007). Highly profitable firms tend to declare and pay high dividend (Amidu and Abor, 2006), which indicated that dividend decision of firms based on their realized earnings for the same year (AlKuwari, 2009).

The study focused on property and real estate sector companies listed in Indonesia Stock Exchange (IDX) during 4 year periods of 20092012. Property and real estate sector has an important role in the economy of Indonesia. This sector indicates an increasing grown development through 2009-2012. Moreover, the increasing number of Indonesian population every year is showing a promising prospect of property and real estate sector. Referring to the previous research conducted by many authors, this study will examine the influence of capital structure and firm size on profitability and dividend policy in property and real estate sector listed on Indonesian Stock Exchange (IDX) during the periods of 2009 to 2012 .

Following the background, this study aims to answer these questions:

1. Does Capital Structure have a significant influence on Profitability?

2. Does Firm Size have a significant influence on Profitability?

3. Does Capital Structure have a significant influence on Dividend Policy? 
4. Does Firm Size have a significant influence on Dividend Policy?

5. Does Profitability have a significant influence on Dividend Policy?

\section{THEORITICAL BACKGROUND AND HYPOTESIS}

\section{A. Capital Structure}

Capital structure is the mixture of debt and equity to finance firm's assets represented by debt, preferred stock, and common stock equity (Brigham and Daves, 2007; Ehrhardt and Brigham, 2009; Horne and Wachowicz, 2008). The first understanding of capital structure developed by Modigliani and Miller or "capital structure irrelevance" proposition based on perfect capital markets, homogenous expectations, no taxes, and no transaction costs (Abor, 2005). In other words, the value of the firm is always the same under different capital structures (Ross et al., 2003). MM Theory then stimulated serious debates devoted to disproving those irrelevances. As a result, trade-off theory, pecking order theory and agency theory were born.

The traditional trade-off theory emphasizes taxes and financial distress. This theory aims to maximize firm value (Brealey and Myers, 2003). Ross et al. (2003) stated the implications of trade-off theory are the balance between tax shield and distress costs, and profitable firms create greater debt capacity.

The pecking-order theory starts with asymmetric information. This starts in which investment is financed first with internal funds, reinvested earnings primarily; then by new issues of debt. Finally companies will issues new equity as the last resort (Brealey and Myers, 2003).

In agency theory, it is assumed that the principal and the agent are motivated by selfinterest. The shareholders, hoping that the agents will act in the shareholders' best interests (Horne and Wachowicz, 2008). Higher levels of debt may affect the behavior of managers to reduce the wasteful spending on non-necessary expenditures, which caused by the threat of bankruptcy (Brigham and Daves, 2007).

\section{B. Firm Size}

The size of a firm is the amount and variety of production capacity and ability a firm possesses or the amount and variety of services a firm can provide concurrently to its customers (Niresh and Velnampy, 2014). There are three main theories proposed by several authors, who believe that firm size matters; principal-agent theory, strategic theories, and institutional theory. Principal-agent theory or so called agency theory explained that the separation of interest between managers and owners may lead to different goal of the firm. Strategic theories viewed that the larger the size of the firm the larger the capability and abilities owned by firm compared with its competitors. Institutional theory described that firms will gradually become more similar in behavior and business approach (Jensen and Meckling, 1976; Jónsson, 2007 Pervan, 2012).

\section{Profitability}

Profitability is the extent to which a firm is profitable (Ross et al., 2003) Profitability is the net result of a number of policies and decisions. The ratios examined thus far provide useful clues as to the effectiveness of a firm's operations, but the profitability ratios go on to show the combined effects of liquidity, asset management, and debt on operating result (Ehrhardt and Brigham, 2009).

\section{Dividend Policy}

Dividend policy is defined as the trade-off between retaining earnings on the other hand and paying out cash and issuing new shares on the other" (Brealey and Myers, 2003). Keown et al. (2008) stated that a firm's dividend policy includes two basic components. First, dividend payout ratio indicates the amount of dividends paid relative to the company's earnings. The second component is the stability of dividends over time.

Miller-Modigliani argued that the value of the firm is determined solely by the earning power of the firm's assets or its investment policy, and that the manner in which the earnings stream is split between dividends and retained earnings do not affect this value (Horne and Wachowicz, 2008). Their statements are hotly debated in academic circles. Bird-in-the-hand theory explains that a stock's risk declines as dividends increase (Ehrhardt and Brigham, 2009), and a higher payout ratio will reduce the required rate of return (cost of capital), and hence increase the value of the firm (AlMalkawi, 2007).

Tax Preference Theory suggests that dividends are subject to a higher tax cut than capital gains (Al-Kuwari, 2009). Hence, investors prefer retained earnings than the 
payment of dividend because of the tax-related reasons (Ehrhardt and Brigham, 2009). The study by Machfiro and Sukoharsono (2013) suggests that investors are more interested in the short term profit through capital gains compared with a dividend.

Clientele effect hypothesis suggest that different clientele or stockholders may prefer different dividend payout policies. Individuals in high tax brackets likely prefer either no or low dividends. The investors in low or even zero tax brackets are has no concern of taxes, but on the other hand stockholders in their peak years might prefer to reinvestment. The clientele effect only warns firms to avoid making capricious changes in their dividend policy (Brigham and Daves, 2007; Keown et al., 2002; Ross et al., 2003).

Information Content, or Signaling, Hypotheses describe that investors may use a change in dividend policy as a signal about the firm's financial condition, especially its earnings power (Keown et al., 2002). An increase in dividend is often accompanied by increase in the price a stock, while a dividend cut generally leads a stock decline. The last issue in dividend policy is Agency Theory of Dividend Policy, which explains that high payouts of dividend will reduce the risk of agency costs (Ehrhardt and Brigham, 2009).

\section{Conceptual Framework And Hypotheses}

Figure below shows the hypothesis framework. The hypotheses formulated as follows:

H1: Capital Structure has a significant influence on Profitability

H2: Firm size has a significant influence on Profitability

H3: Capital Structure has a significant influence on Dividend Policy

H4: Firm Size has a significant influence on Dividend Policy

H5: Profitability has a significant influence on Dividend Policy

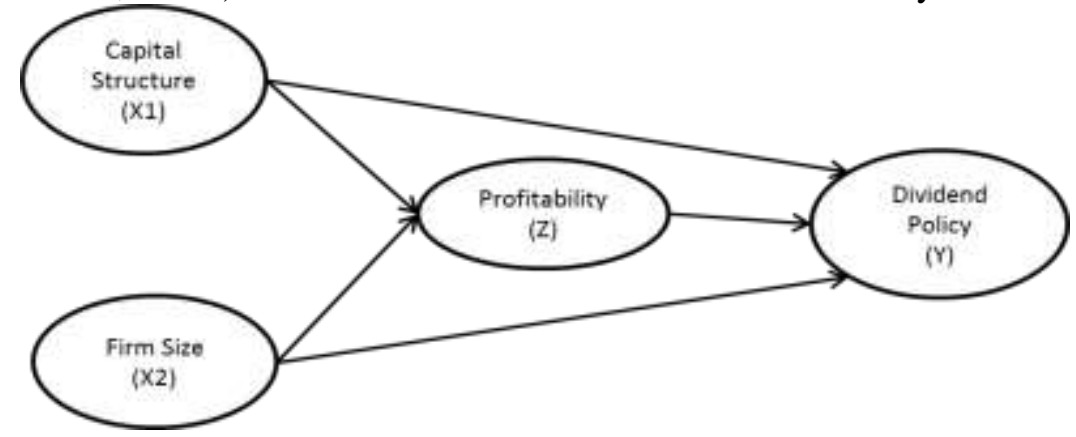

Figure 1 Conceptual framework

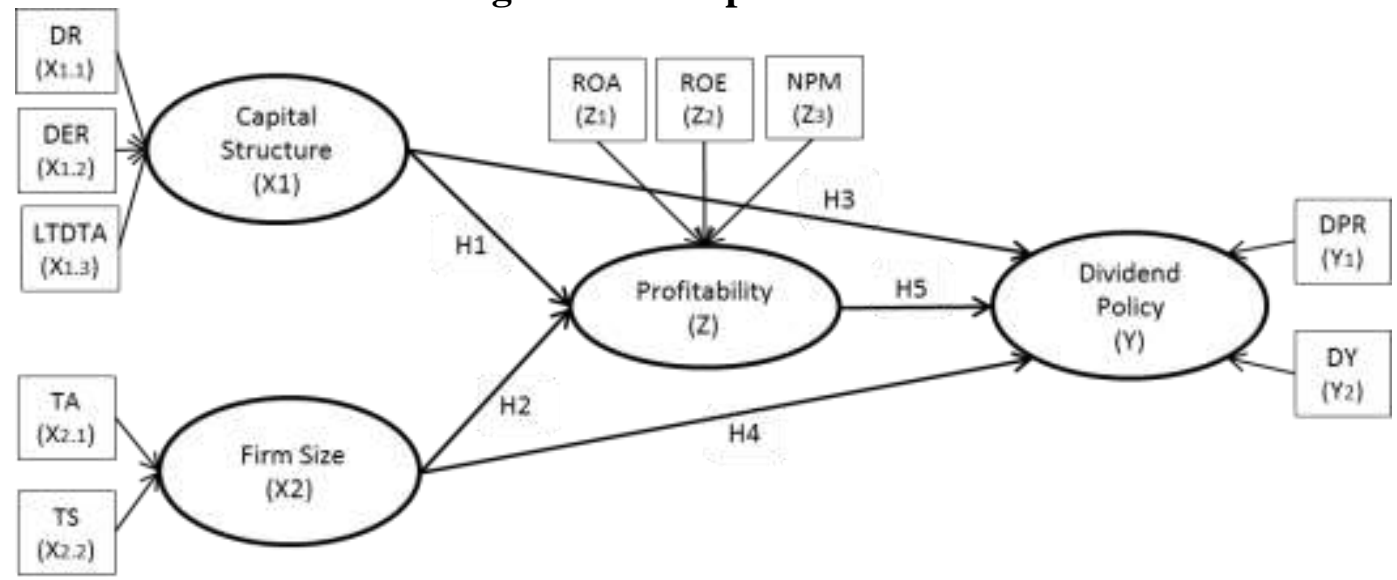

Figure 2 Hypothesis Model 


\section{METHOD}

\section{A. Data and Sample}

The sample used in the study was obtained from IDX website (www.idx.co.id), which focused on property and real estate sector. There were 36 samples of 9 companies that publish full financial statements and distributes cash dividend for four consecutive years from 2009 to 2012 observation periods.

\section{B. Operational Definitions}

a. Capital Structure $\left(\mathrm{X}_{1}\right)$ was measured using the following indicators:

(1) Debt Ratio $\left(X_{1.1}\right)$

(2) Debt to Equity Ratio $\left(X_{1.2}\right)$

(3) Long-Term Debt to Total Assets $\left(X_{1.3}\right)$

b. Firm Size $\left(X_{2}\right)$ was measured using the following indicators:

(1) Total Assets $\left(X_{2.1}\right)$

(2) Total Sales $\left(X_{2.2}\right)$ c. Profitability $(\mathrm{Z})$ was measured using the following indicators:

(1) Return on Assets $\left(Z_{1}\right)$

(2) Return on Equity $\left(Z_{2}\right)$

(3) Net Profit Margin $\left(Z_{3}\right)$

d. Dividend Policy (Y) was measured using the following indicators:

(1) Dividend Payout Ratio ( $\left.Y_{1}\right)$

(2) Dividend Yield $\left(\mathrm{Y}_{2}\right)$

\section{Data Analysis Method}

Data analysis method in this research used Partial Least Square (PLS) by smart PLS software. Data analysis technique using PLS considered appropriate because the model in this research is structural form consisting of more than one dependent variable. Chin et al., (2003) stated that PLS is a powerful method of analysis because of its ability to model latent constructs under conditions of non-normality and small to medium sample sizes.

\section{RESULT AND DISCUSSION}

A. Evaluation of Outer Model

Table 1 Test of Outer Model

\begin{tabular}{|l|r|r|r|r|r|}
\hline & $\begin{array}{c}\text { Original } \\
\text { Sample (O) }\end{array}$ & $\begin{array}{c}\text { Sample } \\
\text { Mean (M) }\end{array}$ & $\begin{array}{c}\text { Standard } \\
\text { Deviation } \\
\text { (STDEV) }\end{array}$ & $\begin{array}{c}\text { Standard } \\
\text { Error } \\
\text { (STERR) }\end{array}$ & $\begin{array}{c}\text { T Statistics } \\
(\mathbf{| O / S T E R R | )}\end{array}$ \\
\hline DER -> CS & 0.720255 & 0.728708 & 0.093900 & 0.093900 & 7.670476 \\
\hline DR -> CS & 0.979162 & 0.941878 & 0.058670 & 0.058670 & 16.689394 \\
\hline LTDTA -> CS & 0.435319 & 0.469419 & 0.162117 & 0.162117 & 2.685220 \\
\hline FSTA -> FS & 0.331064 & 0.424837 & 0.340254 & 0.340254 & 0.972992 \\
\hline FSTS -> FS & 0.972361 & 0.886306 & 0.209770 & 0.209770 & 4.635363 \\
\hline ROA -> P & 0.887508 & 0.867738 & 0.084461 & 0.084461 & 10.507947 \\
\hline ROE -> P & 0.531677 & 0.572546 & 0.121017 & 0.121017 & 4.393387 \\
\hline NPM -> P & 0.893019 & 0.854311 & 0.104468 & 0.104468 & 8.548245 \\
\hline DPR -> DP & 0.952086 & 0.900481 & 0.109280 & 0.109280 & 8.712362 \\
\hline DY -> DP & 0.969862 & 0.882423 & 0.183012 & 0.183012 & 5.299445 \\
\hline
\end{tabular}

Note: if t-value greater than 1.96, it means the indicator is significant or valid at the significance level of $5 \%$

The evaluation of outer model of PLS aims to find out the indicators that both valid and significant in order to assess the validity and reliability of the model. Indicator is considered valid or significant if $\mathrm{t}$-value is greater than 1.96 at the significance level of 5\% (Hair et al., 2011). As shown in Table 1, Capital Structure indicators (DR, DER, and LTDTA) are valid and significant. ROA, ROE, and NPM are valid or significant to measure Profitability. DPR and DY are valid or significant to measure Dividend Policy. FSTS is valid or significant to measure
Firm Size variable, meanwhile FSTA should be dropped out from the model because did not meet the criteria. FSTA has t-value 0.973 or lower than $1.96(\mathrm{p}<0.05)$. 


\section{B. Hypothesis Testing}

Table 2 Hypothesis Testing of Inner Model

\begin{tabular}{|l|c|r|r|r|r|}
\hline & $\begin{array}{c}\text { Original } \\
\text { Sample } \\
(\mathbf{O})\end{array}$ & $\begin{array}{c}\text { Sample } \\
\text { Mean (M) }\end{array}$ & $\begin{array}{c}\text { Standard } \\
\text { Deviation } \\
(\text { STDEV) }\end{array}$ & $\begin{array}{c}\text { Standard } \\
\text { Error } \\
(\text { STERR) }\end{array}$ & $\begin{array}{c}\text { T Statistics } \\
(\mid \mathbf{O} / \text { STERR|) }\end{array}$ \\
\hline CS -> P & -0.867160 & -0.875479 & 0.050233 & 0.050233 & 17.262799 \\
\hline FS -> P & 0.024305 & 0.016274 & 0.098347 & 0.098347 & 0.247137 \\
\hline CS -> DP & 0.015169 & -0.034838 & 0.307443 & 0.307443 & 0.049339 \\
\hline FS -> DP & 0.315240 & 0.335139 & 0.090830 & 0.090830 & 3.470668 \\
\hline P -> DP & 0.623698 & 0.609055 & 0.297981 & 0.297981 & 2.093081 \\
\hline
\end{tabular}

Note: if t-value greater than 1.96 , it means the indicator is significant or valid at the significance level of $5 \%$

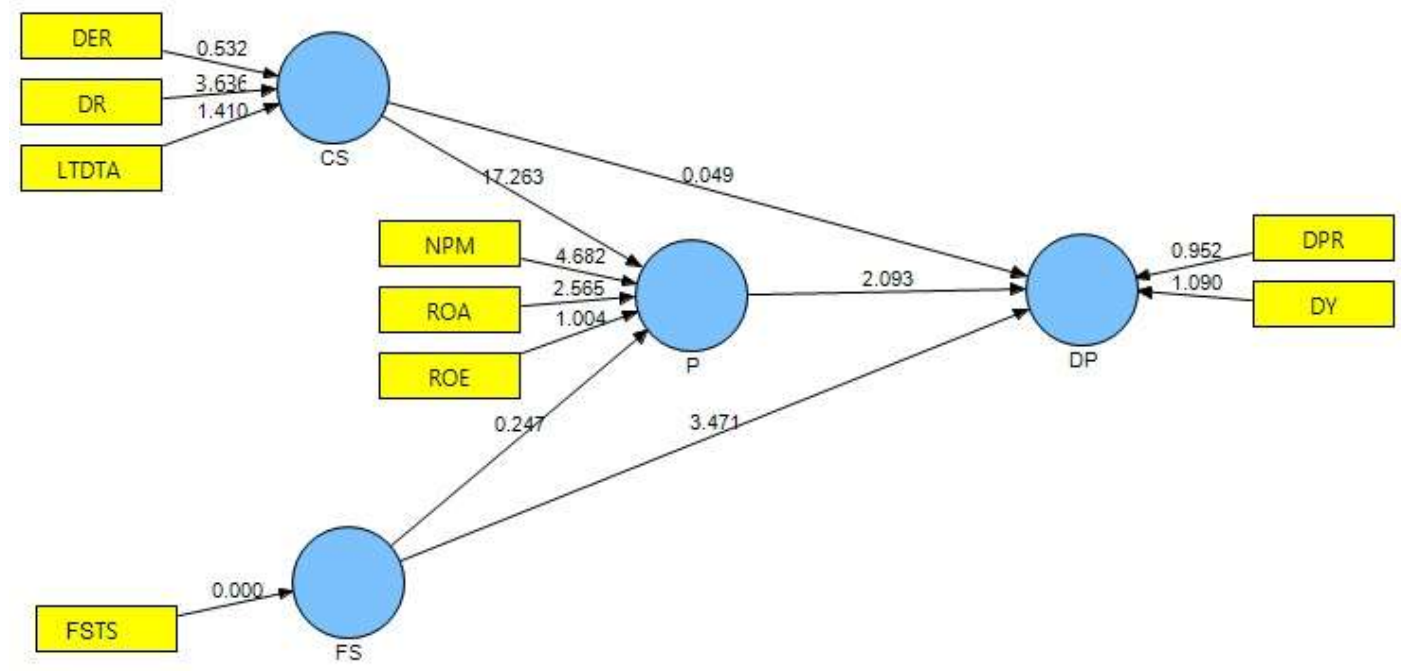

Figure 3 Hypothesis Testing Model (after model fit)

The intervening role of profitability to test the influence of capital structure and firm size on dividend policy was examined according to Baron and Kenny (1986) criteria in mediating test. Sobel equation is used to measure the indirect influence between intervening variable with dependent variable.

a. T-value of the indirect influence from capital structure on dividend policy through profitability is 2.075 , which is greater than 1.96. It means that profitability has significant intervening role in the influence of capital structure on dividend policy.

b. T-value of the indirect influence from firm size on dividend policy through profitability is 0.163 , which is lower than 1.96. It can be concluded that the direct effect of firm size on dividend policy is higher (3.47) than the indirect effect (0.221).
C. Goodness of Fit Inner Model Table 3 R-Square Result

\begin{tabular}{|l|c|}
\hline & R Square \\
\hline Profitability & 0.756063 \\
\hline Dividend Policy & 0.509287 \\
\hline
\end{tabular}

Structural model of PLS is measured using $\mathrm{Q}^{2}$ value.

$$
\begin{aligned}
& \mathrm{Q}^{2}=1-\left(1-\mathrm{R}_{1}^{2}\right)\left(1-\mathrm{R}_{2}^{2}\right) \ldots\left(1-\mathrm{R}_{\mathrm{p}}^{2}\right) \\
& \mathrm{Q}^{2}=1-(1-0.756063)(1-0.509287) \\
& \mathrm{Q}^{2}=1-(0.243937)(0.490713) \\
& \mathrm{Q}^{2}=1-0.119703057 \\
& \mathrm{Q}^{2}=0.880296943
\end{aligned}
$$

The $\mathrm{Q}^{2}$ value is 0.8803 , which indicates that the model can explain $88 \%$, while $12 \%$ explained by another variables that are not contained in the study and error. Thus, the relationship model is considered well described. 


\section{Evaluation of Inner Relations}

\section{a. The Influence of Capital Structure on} Profitability

A negative and significant influence of capital structure on profitability has been found. PLS analysis shows the coefficient parameter $(-0.8671)$ and $t$-statistic 17.262 or higher than t-table 1.96 (p-value<0.05). The significant negative influence explain that the higher capital structure tend to decrease profitability, and conversely.

High capital structure is a usual case in property and real estate sector. Property and real estate sector may interpret the loan as a positive step, imagining that the company preferred that type of financing because it anticipates high returns. But a high capital property and real estate business usually require a relatively long period in development. This may be caused by site selection error, difficulty permitting development, errors in planning and technical development. These situations caused a difficulty in marketing, which lead to large interest expense. A high interest charges might lead the property and real estate companies get a lower profitability.

This finding is supported by Shubita and Alsawalhah (2012); Azhagaiah and Gavoury (2011); Abor (2005). This result is in line with the pecking order theory by Myers and Majluf (1984), in which investment is financed first with internal funds; then by new issues of debt; and finally with new issues of equity. The characteristics of Pecking Order Theory are there is no target amount of leverage, profitable firms use less debt, and the tendencies to like financial slack.

\section{b. The Influence of Firm Size on Profitability}

The result found that there is nonsignificant and a positive influence of firm size on profitability. PLS analysis shows the coefficient parameter $(0.0243)$ and t-statistic 0.2471 , which lower than t-table 1.96 (pvalue $<0.05)$. Non-significant correlation explains that the level of firm size will not increase or decrease the profitability of property and real estate companies listed in Indonesia Stock Exchange during the observation periods of 2009-2012.

Total sales or revenue generated by companies will be diverted or used to pay their obligations or debt taken by the company.
Total sales as the only indicator that support firm size variable may lead to biased results. Moreover, total asset as one indicator measuring the size of property and real estate companies may be funded from loans taken by the company. Therefore, the size of property and real estate companies proved no significant on profitability. The result supported by several researchers such as Tapanjeh (2006) and Niresh and Velnampy (2014), stated that firm size have no significant effects on profitability.

\section{c. The Influence of Capital Structure on Dividend Policy}

A positive and non-significant result has been found in the relationship between capital structure and dividend policy. PLS analysis shows the coefficient parameter $(0.0151)$ and $t-$ statistic 0.0493 , which lower than t-table 1.96 ( $p$-value<0.05). Meanwhile, it has been found a significant relationship between capital structure and dividend policy through profitability. The indirect effect is measured by Sobel calculation conducted earlier, which proved that profitability is significant as the intervening variable. A positive relationship between capital structure and dividend policy in property and real estate sector companies is regarded as the payment of dividends on the reciprocal of the return on funds invested.

The use of leverage or capital structure decisions will affect the profit earned by company including dividend payment decision. The payment of dividend tend to fluctuate because high use of leverage will be followed by a high beta coefficient, high fixed costs covered by the company and low profitability, hence affect the payment of dividends. Revenue growth opportunities in terms of investment in the future also may affect the company's dividend policy.

This finding is similar with Marlina and Danica (2009), and Megawati (2011), who stated that capital structure has no significant effect on Dividend Payout Ratio (DPR). Hardjopranoto (2006) stated that leverage policy does not influence dividend policy because the company will decide its dividend policy based on the investors' preferences or so called clientele effect.

The result is contradict with the findings by Al-Kuwari (2009); Hasyemi and Zadeh (2012); and Al-Malkawi (2007). Their research shows 
capital structure is statistically significant and negatively associated with dividend payout.

\section{d. The Influence of Firm Size on Dividend Policy}

A positive and significant result has been found between firm size and dividend policy. PLS analysis shows the coefficient parameter (0.3152) and t-statistic 3.4706, or higher than ttable 1.96 ( $\mathrm{p}$-value<0.05). The significant positive influence explain that the higher firm size tend to increase dividend policy, and conversely. Manager knows more about the company's condition and act as the agent of principal. They are expected to engage in interpersonal role, informational, and decisional role (Sukoharsono, 2008). Their decisions could potentially cause agency problems. The larger the property and real estate company, the more difficult (costly) is the monitoring (i.e. the greatest the agency problem). Agency problem will leads the company face more delegacy costs because delegacy costs increasing complexities and in capability of shareholders. Hence, dividends could play a role in helping to alleviate the agency problem.

Dividend payment announcement followed by high sales or revenue generated by the companies is seen as a good signal that the company condition is good (information content of dividend or signaling hypothesis). Large companies tend to distribute high dividends to maintain a reputation among investors, while the small size company will allocate their income to retained earnings, which will be used to acquire assets or reinvest, so companies tend to distribute lower dividends. The result is similar with Al-Kuwari (2009); Al-Malkawi (2007); Hasyemi and Zadeh (2012).

\section{e. The Influence of Profitability on Dividend Policy}

The last hypothesis testing result shows that there is a positive and significant influence of profitability on dividend policy. PLS analysis shows the coefficient parameter (0.6236) and tstatistic 2.093, which higher than t-table 1.96 ( $\mathrm{p}$-value $<0.05)$. The significant positive influence explain that the higher profitability tend to increase dividend policy, and conversely.

Profitability has long been regarded as the primary indicator of the level of dividends paid.
Highly profitable firms tend to declare and pay high dividend, which indicated that dividend decision of firms based on their realized earnings for the same year. The pecking order hypothesis may provide an explanation between profitability and dividends. That is, taking into account the costs of issuing debt and equity financing, less profitable firms will not find it optimal to pay dividends, ceteris paribus. On the other hand, highly profitable firms are more able to pay dividends and to generate internal funds (retained earnings) to finance investments. The result has a similar findings as Al-Malkawi (2007); Amidu and Abor (2006); and Al-Kuwari (2009).

\section{Research Limitation}

1. The sample of the study is limited only on property and real estate sector, and the sample size is relatively small.

2. The study found insignificant results, those are the firm size variable has positive and non-significant influence on profitability, and capital structure has insignificant positive influence on dividend policy.

3. Firm Size Total Asset (FSTA) should be dropped out from the model, which caused Firm Size Total Size (FSTS) as the single indicator supporting Firm Size variable. This may lead to biased results that will affect the other dependent variable.

\section{CONSLUDING REMARK CONCLUDING}

The study is performed in order to test the relationship between capital structure and firm size on profitability and dividend policy. The study focused on dividend policy because the researcher wanted to see from investor's perspective, where dividend policy is seen as a good signal on the financial condition of the company. The study is conducted in property and real estate sector companies listed in IDX during the periods of 2009-2012.

Property and real estate sector Indonesia is chosen because this sector indicates an increasing grown development and the increasing number of Indonesian population every year is showing a promising prospect of property and real estate sector. Moreover, property and real estate sector uniqueness is their capability to collect a lot of equity or capital in the form of debt and still able to 
produce great profits regardless of the size of the firm.

The result shows that Capital Structure has a negative significant influence on Profitability and Firm Size has positive but not significant influence on Profitability. Capital structure has positive but not significant influence on Dividend Policy. The study also shows that Firm Size is significant positively influence Dividend Policy. Lastly, Profitability has a positive and significant relationship to Dividend Policy.

\section{REMARK}

1. It is suggested to conduct the study not only in property and real estate sector, but also in another sectors; and extending the observation period that might deliver a better research result.

2. It is also suggested for future research to examine other financial variables such as ownership structure, cash flow, firm growth, business risk, and etc. Additional indicators in each variable are also recommended that will further enrich the study.

3. For company, capital structure and firm size has proven as factors affecting profitability and dividend policy, thus the results should be useful as an information to decide on the extent which indicators needs to be monitored and controlled.

4. For investor, it is advisable to analyze the financial condition, assessing the financial posts related to dividend to be distributed and profitability obtained by the company.

5. For government, it is suggested to improve the government regulations regarding the ease in taking the loan funds as an effort to stimulate the growth and dynamics of property and real estate sector

\section{REFERENCES}

Abor, Joshua. 2005. "The Effect of Capital Structure on Profitability: An Empirical Analysis of Listed Firms in Ghana". The Journal of Risk Finance 6 (5): 438-445.

Al-Kuwari, Duha. 2009. "Determinants of the Dividend Policy in Emerging Stock Exchanges: The Case of GCC Countries". Global Economy \& Finance Journal 2 (2): 38-63.

Al-Malkawi, H. A. Nizar. 2007. "Determinants of Corporate Dividend Policy in Jordan: An Application of the Tobit Model". Journal of
Economic \& Administrative Sciences 23 (2): 44-70.

Amidu, M. and J. Abor. 2006. "Determinants of Dividend Payout Ratios in Ghana". The Journal of Risk Finance 7 (2): 136-145.

Azhagaiah, R. and C. Gavoury. 2011. "The Impact of Capital Structure on Profitability with Special Reference to IT Industry in India". Managing Global Transitions 9 (4): 371-392.

Babalola, Y. A. 2013. "The Effect of Firm Size on Firms Profitability in Nigeria". Journal of Economics and Sustainable Development 4 (5):90-94.

Baron, R. M. and D. A. Kenny. 1986. "The Moderator-Mediator Variable Distiction in Social Psychological Research: Conceptual, Strategic, and Statistical Considerations". Journal of Personality and Social Psychology 51: 1173-1182.

Brealey, R. A. and S. C. Myers. 2003. Principles of Corporate Finance 7th edition. New York: The McGraw-Hill Companies, Inc.

Brigham, Eugene F. and P.R. Daves. 2007. Intermediate Financial Management 9th edition. Mason: Thompson/South-Western.

Chin, W. W., B. L. Marcolin, and P. N. Newsted. 2003. "A Partial Least Squares Approach for Measuring Interaction Effects: Results from a Monte Carlo Simulation Study and An Electronic Mail Emotion/Adoption Study". Information Systems Research, 14(2), 189-217.

Ehrhardt, M. C., and E. F. Brigham. 2009. Financial Management: Theory and Practice, 13th Edition. Mason: SouthWestern Cengage Learning.

Gill, Amarjit, N. Biger, and N. Mathur. 2011. "The Effect of Capital Structure on Profitability: Evidence from the United States". International Journal of Management 28 (4): 3-15.

Hair, J. F., C. M. Ringle, and M. Sarstedt. 2011. "PLS-SEM: Indeed a Silver Bullet". Journal of Marketing Theory and Practice 19 (2): 139-151.

Hardjopranoto, Wibisono. (2006). "Interdependent Analysis of Leverage, Dividend, and Managerial Ownership 
Policies: Agencies Perspectives". Gadjah Mada International Journal of Business 8 (2): 179-199.

Hasyemi, S. A. and F. Z. K. Zadeh. (2012). "The Impact of Financial Leverage Operating Cash Flow and Size of Company on The Dividend Policy: Case Study of Iran". Interdisciplinary Journal of Contemporary Research in Business 3 (10):264-270.

Horne, J. C. V. and J. M. Wachowicz, Jr. 2008. Fundamental of Financial Management 13th edition. Essex: Prentice Hall, Inc.

Jensen, M., and Meckling, W. 1976. "Theory of The Firm: Managerial Behavior, Agency Cost, and Ownership Structure". Journal of Financial Economics 3: 305-360.

John, A. O. and O. Adebayo. 2013. "Effect of Firm Size on Profitability: Evidence from Nigerian Manufacturing Sector". Prime Journal of Business Administration and Management (BAM) 3(9): 1171-1175.

Jónsson, B. 2007, “Does The Size Matter? The Relationship Between Size and Profitability of Icelandic firms", Bifröst Journal of Social Science 1: 43 - 55.

Keown, A. J., J. D. Martin, J. W. Petty, and D. F. Scott, Jr. 2002. Financial Management: Principles and Applications 9th edition. New Jersey: Pearson Education, Inc.

Machfiro, S., and E. G. Sukoharsono. 2013. "The Effect Of Financial Variables On The Company's Value: Study of Food and Beverage Companies that are listed on Indonesia Stock Exchange Period 20082011”. Journal FEB UB 1(1): 1-9.

Marlina, L. and C. Danica, 2009. "Analysis of Effect of Cash Position, Debt to Equity Ratio and Return on Assets on Dividend Payout Ratio in Manufacturing Company in Indonesia". Journal of Business Management 2 (1): 1-6.

Megawati, V. 2011. "Analysis of Factors Affecting Dividend Payout Ratio in Manufacturing Company Listed in Indonesia Stock Exchange". FE University of Pembangunan Nasional "Veteran", Yogyakarta.

Myers, S.C. and N.S. Majluf. 1984. "Corporate Financing and Investment Decisions When Firms Have Information that Investors Do
Not Have". Journal of Financial Economics, 13: 187-221.

Niresh, J. A. and T. Velnampy. 2014. "Firm Size and Profitability: A Study of Listed Manufacturing Firms in Sri Lanka". International Journal of Business and Management 9 (4): 57-64.

Pervan, M., and Josipa Višić. 2012. "Influence of Firm Size on Its Business Success". Croatian Operational Research Review (CRORR),3: 213-223.

Ross, S. A., R.W. Westerfield, and J. Jaffe. 2003. Corporate Finance 6th edition. New York: The McGraw-Hill/Irwin.

Shubita, M. Fawzi and J. M. Alsawalhah. 2012. "The Relationship between Capital Structure and Profitability". International Journal of Business and Social Science 3 (16): 104-112.

Suhoharsono, E. Ganis. 2008. Sistem Informasi Manajemen. Malang: Surya Pena Gemilang.

Tapanjeh, A. M. Abu. 2006. “An Empirical Study of Firm Structure and Profitability Relationship: The Case of Jordan". Journal of Economic \& Administrative Sciences 22(1): 41-59.

Vijayakumar, A. 2011. "An Empirical Study of Firm Structure and Profitability Relationship: The Case of Indian Automobile Firms". International Journal of Research in Commerce, IT and Management 1(2): 100-109. 